\title{
MOLECULAR CHARACTERIZATION OF JABOTICABA TREE GENOTYPES LOCATED IN THE MUNICIPALITIES OF RECÔNCAVO OF BAHIA ${ }^{1}$
}

\author{
ELAINE SILVA DA CRUZ², ANA CRISTINA VELLO LOYOLA DANTAS ${ }^{3}$, \\ CÁTIA DIAS DO CARMO², LUCIMÁRIO PEREIRA BASTOS ${ }^{4}$
}

\begin{abstract}
The jaboticaba tree (Plinia sp.) is a native fruit tree belonging to the Myrtaceae family, which occurs spontaneously throughout Brazil. The estimation of genetic divergence among genotypes of native populations can be useful for conservation and knowledge of available genetic resources, in the formation of gene banks and breeding species. In order to evaluate the genetic diversity of jaboticaba trees identified in the Bahia Reconcavo municipalities, 35 genotypes were characterized by ISSR primers (Inter Simple Sequence Repeats). The 18 primers generated a total of 463 amplicons, and the number of initiator fragments ranged from 14 to 36 , with an average of $25.72 \%$ and $99.65 \%$ polymorphism. Polymorphic information content ranged from 0.13 to 0.33 with a mean of 0.22 and the marker resolution power from 4.34 to 15.77 , with an average of 8.67. Multivariate analysis allowed the formation of five groups of genetic divergence, where the longest distance was 0.97 between JCA6 and JSF8 genotypes and the lower of JMT2 and JCA1 (0.11). From the use of ISSR markers it is possible to check the variability between genotypes on the evaluated jaboticaba trees.
\end{abstract}

Index terms: genetic diversity, ISSR, Plinia sp.

\section{CARACTERIZAÇÃO MOLECULAR DE GENÓTIPOS DE JABUTICABEIRA LOCALIZADOS EM MUNICÍPIOS DO RECÔNCAVO DA BAHIA}

RESUMO - A jabuticabeira (Plinia sp.) é uma frutífera nativa pertencente à família Myrtaceae, de ocorrência espontânea em grande parte do Brasil. A estimativa da divergência genética entre genótipos de populações nativas pode ser útil para a conservação e conhecimento dos recursos genéticos disponíveis, visando a formação de bancos de germoplasma e melhoramento genético da espécie. Com o objetivo de avaliar a diversidade genética de jabuticabeiras identificadas em municípios do Recôncavo da Bahia, foram caracterizados 35 genótipos por meio de iniciadores ISSR (Inter Simple Sequence Repeats). Os 18 iniciadores geraram um total de 463 fragmentos de amplificação, sendo que o número de fragmentos por iniciador variou de 14 a 36 , com uma média de 25,72 e polimorfismo de $99,65 \%$. O conteúdo de informação polimórfica variou de 0,13 a 0,33 com média de 0,22 e o poder de resolução do marcador de 4,34 a 15,77, com uma média de 8,67. A análise multivariada possibilitou a formação de cinco grupos de divergência genética, em que a maior distância foi de 0,97 entre os genótipos JCA6 e JSF8 e a menor entre o JMT2 e JCA1 $(0,11)$. A partir da utilização dos marcadores ISSR é possível verificar a variabilidade existente entre genótipos de jabuticabeira avaliados.

Termos para indexação: diversidade genética, ISSR, Plinia sp.

'(Trabalho 056-15). Recebido em: 09-02-2015 Aceito para publicação: 07-10-2015

${ }^{2}$ Mestre em Recursos Genéticos Vegetais - Universidade Federal do Recôncavo da Bahia/Embrapa. E-mails: elainesc_agr@yahoo. com.br; catiadiasdocarmo@gmail.com

${ }^{3} \operatorname{Prof}^{\mathrm{a}} \mathrm{Dr}^{\mathrm{a}}$ - Universidade Federal do Recôncavo da Bahia. E-mail:acloyola@ufrb.edu.br

${ }^{4}$ Doutorando em Ciências Agrárias - Universidade Federal do Recôncavo da Bahia. E-mail: agronero@yahoo.com.br 


\section{INTRODUCTION}

The jaboticaba (Plinia sp.) is a fruit tree belonging to the Family Myrtaceae, of natural occurence in most parts of Brazil. This fruit tree is of significant economic potential, where its fruits are very appreciated mainly due to its organoleptic qualities, use by the pharmaceutical and food industry (SASSO et al., 2010), but its exploration still occurs in a extractive way.

The jaboticaba consist in a group of nine botanical species, and due to problems regarding the taxonomical classification, a change in the nomenclature, from the genus Myrciaria to the genus Plinia, was proposed by Sobral (1985). However, the genus Myrciaria is still widely used in the scientific working groups to the botanical classification of jaboticabeira tree. The information about its reproductive behavior are still scarce and divergent, needing deeper studies. Danner et al. (2011a) identified two species (Plinia trunciflora (O. Berg) Kausel and Plinia jaboticaba (Vell.) Kausel) which are self-compatible and one allogamous species (Plinia cauliflora (DC.) Kausel). Nonetheless, Vilella et al. (2012), in experiments about the reproductive system, found Plinia cauliflora (DC.) Kausel as a self-compatible species. Studies of cromosomal characterization in jaboticabeiras are also rare and not fully understood. Costa and Forni-Martins (2006) found a number of chromosomes of $2 \mathrm{n}=22$ for Plinia cauliflora (DC.) Kausel. Silveira et al. (2006) found a number of chromosomes of $2 \mathrm{n}=22$ in Myrciaria cauliflora (Mart.) O. Berg and $2 \mathrm{n}=48$ for Myrciaria trunciflora (O. Berg) Kausel.

The few studies involving the characterization of jaboticabeiras are based on morphological evaluations of the trees, fruits and seeds, regarding basically physical, chemical, physical-chemical, and germinal characters, that have shown the existence of variability in the species (DANNER et al., 2011b; GUEDES et al. 2014; WAGNER JÚNIOR et al., 2011). However, studies of genetic diversity in jaboticabeiras using molecular markers are incipient.

Characterization of genotypes using morphoagronomic markers can produce subjective results since they are under the influence of environmental factors. Thus, the molecular markers allow to access the genetic variability in the DNA level, without the interference caused by environment, contributing to the process of characterization and selection of superior genotypes (FERREIRA; GRATTAPAGLIA, 2008).

A marker of great applicaton in breeding program is the ISSR (Inter Simple Sequence Repeats), based in the information of microsatellites, but do not need previous information of the DNA sequences of the target species. Its amplification occurs via PCR (Polymerase Chain Reaction) in the presence of complementary oligonucleotides of microsatellite motifs, which can be anchored in the extremity $3^{\text {' }}$ or 5' with 1 to 4 purine or pyrimidine bases. Because it is a dominat marker, the ISSR do not differentiates heterozygous and homozygous subjects, but it offers the advantage of analyzing multiple loci in a single reaction (GOULÃO; OLIVEIRA, 2001).

Compared to other nonspecific PCR based markers, such as RAPD (Random Amplified Polymorphic DNA), the ISSR produce fragments with great reproducibility because they are more robust, since they show a larger anchoring surface and have higher annealing temperatures (REDDY et al., 2002). Thus, this marker has been widely used as a supporting tool in breeding programs to characterize and access the genetic variability of several species (DIAS et al., 2015; OLADOSU et al., 2015; OLIVEIRA et al., 2014).

The molecular characterization is, therefore, a tool of great importance for genetic conservation and breedig programs, since it generates information, both about the intrinsic characteristics of the species, as its population dynamics (AGUIAR et al., 2013; MELO et al. 2015; SOUZA, 2015).

The estimation of the genetic divergence among genotypes of native populations might be useful for conservation and knowledge of the genetic resources available, aiming the formation of germplasm banks and breeding of the species. The use of characters of agronomical interest in association with multivariate statistics techniques allows the selection of the best genotypes to use in a production system or in breeding studies (CRUZ; CARNEIRO, 2003).

Thus, the objective of this study was to characterize genotypes of jaboticabeira using ISSR markers to assess the existing genetic diversity.

\section{MATERIAL AND METHODS}

Thirty five genotypes of jaboticaba trees were found and georeferenced in nine municipalities of Recôncavo da Bahia: Cabaceiras do Paraguaçu, Cruz das Almas, Governador Mangabeira, Maragogipe, Muritiba Santo Antônio de Jesus, Sapeaçu, São Felipe, and São Félix, constituting isolated materials or small groups in farms, with geographic positions between S $12^{\circ} 08^{\prime} 19^{\prime \prime}$ to S $12^{\circ} 57^{\prime} 77^{\prime \prime}$ and W $039^{\circ} 02^{\prime} 30^{\prime \prime}$ to $\mathrm{W} 039^{\circ} 15^{\prime} 45^{\prime \prime}$, visually considered of the same species of Plinia (Table 1). 
The molecular characterization was performed in the Molecular Biology Lab of the Embrapa Mandioca e Fruticultura. The extraction of genomic DNA was performed using the methodology described in Lodhi (1994), and modified by Pereira (2005). In order to evaluate DNA integrity and standardize its concentration, it was performed quantification in agarose gel $1.0 \%(\mathrm{w} / \mathrm{v})$ stained with ethidium bromide $\left(1.0 \mathrm{mg} \mathrm{ml}^{-1}\right)$ and visually compared with a series of concentrations of DNA phage Lambda (Invitrogen).

To polymorphism detection, 18 primers were applied in the population of the 35 genotypes studied (Table 2). The amplifications were performed according the following program: $94{ }^{\circ} \mathrm{C}$ during 3 minutes, 39 cycles at $94{ }^{\circ} \mathrm{C}$ during 45 seconds, $48{ }^{\circ} \mathrm{C}$ during 45 seconds, $72{ }^{\circ} \mathrm{C}$ during 1 minute, and final extension at $72{ }^{\circ} \mathrm{C}$ during 7 minutes, in a thermocycler Applied Biosystems, model Veriti ${ }^{\circledR}$ 96-well.

The amplification reactions were performed in a final volume of $15 \mu \mathrm{L}$, containing: $20 \mathrm{ng}$ of DNA, $10 \mathrm{mM}$ of Tris- $\mathrm{HCl}$ ( $\mathrm{pH} \mathrm{8.3),} 50 \mathrm{mM}$ of $\mathrm{KCl}$, $0.25 \mathrm{mM}$ of each dNTP, $1.5 \mathrm{mM} \mathrm{MgCl}, 0.3 \mathrm{mM}$ of primer, 1.0 U Taq DNA polimerase (Ludwig Biotec).

The amplification products were separeted by horizontal electrophoresis at $120 \mathrm{~V}$, during 4 hours, in agarose gel at $2.0 \%$, and stained with ethidium bromide, in TBE buffer $0.5 \times$ (TBE $0,5 \times(45 \mathrm{mM}$ Tris-borate, $1 \mathrm{mM}$ EDTA and q.s.p of distilled water). The marker 100pb DNA Ladder (Ludwig Biotec) was used as pattern of molecular size. The visualization of the results were performed with the exposure of the gel to ultraviolet light and photographed with a photo-documentation equipment Vilber Lourmat.

The amplified fragments were recorded in binary code (absence- 0 and presence- 1 ). From these data, the genetic dissimilarity between the 35 genotypes were calculated using the similarity coefficient of Jaccard (1901) and for grouping it was used the UPGMA method- Unweighted Pair Group Method with Arithmetic Mean (SNEATH; SOKAL, 1973). In order to verify the consistence of the grouping the cophenetic correlation coefficient (CCC) was calculated, using the software Genes 7.0 (CRUZ, 2008). Based on the matrix of distances generated the dendrogram was obtained using the software STATISTICA 7.1 (STATSOFT, 2005).

For the definition of the number of groups it was used the package "NbClust" (CHARRAD et al., 2014), belonging to the sofware $R$ version 3.0.1 ( $R$ DEVELOPMENT CORE TEAM, 2013) using the Pseudot2 index (DUDA; HART, 1973) as criteria for grouping and determining the cutoff point.
Two parameters were used to evaluate the discrimination of ISSR primers: polymorphic information content (PIC) and resolution power (RP).

The PIC values for each polymorphic locus were calculated by: $P I C i=1-\sum \mathrm{fi}^{2} \quad$; where $\mathrm{PIC}_{i}$ is the polymorphic information content of the primer $i, f_{i \text { is }}$ the frequency of the allele $\mathrm{i}$ in the population (WEIR, 1990).

The RP was calculated according to Prevost and Wilkinson (1999): $\mathrm{RP}=\sum \mathrm{lb}$; where Ib represents the polymorphic loci. The Ib can be transformed in a scale of $0-1$ using the formula: $l b=1-(2 x|0,5-p|)$ where, $p$ is the proportion of genotypes that contains the locus.

\section{RESULTS AND DISCUSSION}

\section{Polymorphism and discriminatory power of ISSR primers}

The ISSR primers allowed the attainment of 463 amplified fragments. The number of fragments by primer varied from 14 (DiGA3'RC) to 36 (DiGA3'C) with an average of 25.72. Of the 463 fragments, 99.45 resulted in polymorphism, with average of 25.67 polymorphic bands by primer (Table 2). Only the primer TriGGA 3'RC showed monomorphic locus (Figure 1). The high average of fragments by primer and the low percentage of monomorphic primers confirmed the high genetic variability among the genotypes of jaboticabeira analyzed, besides indicating the validation of the ISSR primers tested, which may be used in future characterization studies of genotypes of the species.

It should be emphasized that up to now any study was generated from the use of ISSR markers to evaluate the genetic diversity in jaboticabeira. Through research developed with other species of the same family, it was possible to detect the presence of variability regarding the amount of polymorphic fragments amplified. Oliveira et al. (2014), evaluating the genetic distance among 37 accesses of Psidium spp., using 17 primers, obtained 216 polymorphic fragments, with an average of 13 by primer. Studying the diversity of 272 genotypes of the same species of the jaboticabeira family, Myrcia splendens (SW), Brandão et al. (2011) used 10 primers and identified 70 polymorphic fragments. Mani et al. (2011), evaluating the genetic distance among 15 species of Psidium spp., used 31 ISSR primers and obtained a total of 234 polymorphic fragments.

However, when evaluating the genetic diversity among species of jaboticabeira using RAPD markers, Pereira et al. (2005) characterized 31 plants of Myrciaria spp., using 11 primers, obtained 45 
polymorphic bands. Vilela et al. (2012) assessed 66 individuals of four species through eight primers and obtained only 37 polymorphic bands. The authors observed that this technique showed little differentiation among the species, since it was not possible grouping the plants in interspecific level, besides the generation of few polymorphic bands. This fact is likely due to the low primer specificity that results in a lower quantity of bands when compared to ISSR (REDDY et al., 2002).

The polymorphic infomation content (PIC) and resolution power (RP) are efficient parameters to discriminate the most informative primers. They are widely used in several studies to access the information and discrimination of primers combinations in studies of genetic diversity (TATIKONDA et al., 2009).

The PIC takes into account the total number of fragments detected for each locus to a given primer and the frequency of them in the group of genotypes studied. The PIC represents the presence of variability, where it is greater with the highest values of PIC (BOTSTEIN et al., 1980). The maximum expected value of PIC for biallelic primers is 0.5 , considering the most informative those showing values close to this. In the present study, the PIC ranged from 0.13 for the primer TriCGA 3'RC to 0,33 for the primer TriGAG 3'RC, with average of 0.22 (Table 2). The primers TriGAG 3'RC, DiGA3'YC, and TriCAG5' $\mathrm{CR}$ are the most recommended to analysis in jaboticabeira, because they show the highest values of PIC $(0.33,0.29$, and 0.28$)$ among the evaluated primers.

The power of resolution (RP) is a parameter highly correlated with the capacity of the primer or the combination of primers to differentiate genotypes (PREVOST; WILKINSON, 1999). The values of $\mathrm{RP}$ varied from 4.34 in the primer TriCGA 3'RC to 15.77 in the DiGA3' $C$, with an average of 8.67. There is not a optimum value established for RP, being recommended those showing the greatest values. In this way, the primers DiGA3'C, TriGTC 3'RC, and DiCA5' $G$ showed greater capacity to discriminate the genotypes of jaboticabeira (Table 2).

The primers DiCA5'G, DiGA3'C, TriCAG5'CR, TriTGG 3'RC, and TriGTC 3'RC standed out because they showed the best combinations of values for PIC and RP (Table 2), (VIDAL, et al., 2015) indicating to be the most informative. Thus, these primers show more functionality in the detection of genetic variability in jaboticabeiras, being recommended for future studies.

\section{Analysis of genetic diversity}

The analysis of genetic diversity allowed to obtain a dendrogram whose cophenetic correlation (CCC) between the matrix of genetic dissimilarity and the grouping matrix was positive and highly significant (test $t$ at $5 \%$ of probability), with value of 0.97 for the genotypes in general. Values superior to 0.91 reflect a good agreement among the matrix and, therefore, a high reliability of the dendrogram data (ROHLF; FISHER,1968).

In the genetic diversity dendrogram of the jaboticabeira genotypes it was possible to observe the formation of five diversity groups (Figure 2). The group 1 was represented by only one genotype (JSF8), from São Felipe, indicating a greater divergence of this group relative to the others. The group 2 was composed by the genotypes JSA1, JSFP5, JSFP4, JSFP3, and JMG7, from three different municipalities: Santo Antônio de Jesus, São Felipe, and Maragogipe. Three genotypes from Cruz das Almas (JCA4, JCA5, and JAC3) were gathered in group 3. The group 4 was composed by the genotypes JSFP2, JSF7, JSF6, JMG3, JMG2, JMG1, JSF5, JSF3, JSF1, and JGM1, from São Felipe, São Félix, Maragogipe, and Governador Mangabeira and the group 5: JSFP1, JMG6, JMG5, JMG4, JSF9, JSF2, JCA7, JCA6, JCA2, JSP, JMT1, JCP2, JCA1, JMT2, $\mathrm{JCP} 3$, and JCP1, having at least one representative of each locality.

It was found that the lower genetic distance was 0.11 between the genotype JMT2 (Muritiba) and JCA1 (Cruz das Almas) for the genotypes evaluated, indicating they have very close genetic characteristics. The higher distance was of 0.97 between the genotypes JCA6 and JSF8 from Cruz das Almas and São Félix, respectively. However, it is possible to observe that the geographic distance did not correlate with the genetic distance among the genotypes, where the closest genotypes were from different locations. This might be justified by the exchange and transport of propagation material among growers. This shows that the use of molecular markers allowed the variability expression of the studied material, regardless the sampling region. The knowledge about the variability enables the decision taking with greater precision concerning the conservation and handling of this genetic material, that might be used for breeding programs. 
TABLE 1-Location of the genotypes of jaboticabeira (Plinia sp.) evaluated in the municipalities of Recôncavo da Bahia, BA.

\begin{tabular}{|c|c|c|c|c|}
\hline Genotype & Location & Municipality & Latitude & Longitude \\
\hline JCP1 & Prop. Sr. Moaci & Cab. do Paraguaçu & S 12०37'95" & W 039¹3'91" \\
\hline $\mathrm{JCP} 2$ & Prop. Sr. Tunico & Cab. do Paraguaçu & S $12^{\circ} 34^{\prime} 75^{\prime \prime}$ & W $039^{\circ} 11^{\prime} 32^{\prime \prime}$ \\
\hline JCP3 & Prop. Sr. Tunico & Cab. do Paraguaçu & S 12'34'75" & W $039^{\circ} 11^{\prime} 32^{\prime \prime}$ \\
\hline JMT1 & Prop. Sr. Alcides & Muritiba & S $12^{\circ} 08^{\prime} 19^{\prime \prime}$ & $\mathrm{W} 039^{\circ} 01^{\prime} 41^{\prime \prime}$ \\
\hline JMT2 & Prop. D. Ana & Muritiba & S $12^{\circ} 37^{\prime} 41^{\prime \prime}$ & W $039^{\circ} 05^{\prime} 30^{\prime \prime}$ \\
\hline JSP1 & Prop. Sr. Sinésio & Sapeaçu & S 12'39'39"' & W 039¹3'39'” \\
\hline JCA1 & Prop. Sr. Danilo & Cruz das Almas & S $12^{\circ} 43^{\prime} 81^{\prime \prime}$ & W $039^{\circ} 04^{\prime} 33^{\prime \prime}$ \\
\hline JCA2 & Prop. Sr Sr. Bui & Cruz das Almas & S 12³9'80" & $\mathrm{W} 039^{\circ} 06^{\prime} 28^{\prime \prime}$ \\
\hline JCA3 & Prop. Sr. Leonardo & Cruz das Almas & S 12'39'83" & W $039^{\circ} 05^{\prime} 98^{\prime \prime}$ \\
\hline JCA4 & Prop. Sr. Leonardo & Cruz das Almas & S 12'39'83" & W $039^{\circ} 05^{\prime} 98^{\prime \prime}$ \\
\hline JCA5 & Prop. Sr. Ivo & Cruz das Almas & $\mathrm{S} 12^{\circ} 40^{\prime} 88^{\prime \prime}$ & W $039^{\circ} 05^{\prime} 84^{\prime \prime}$ \\
\hline JCA6 & Prop. Sr. Hermes & Cruz das Almas & S $12^{\circ} 42^{\prime} 81^{\prime \prime}$ & W $039^{\circ} 07^{\prime} 20^{\prime \prime}$ \\
\hline JCA7 & Prop. D. Dulce & Cruz das Almas & S 12'39'63”' & W $039^{\circ} 05^{\prime} 38^{\prime \prime}$ \\
\hline JGM1 & Prop. Sr. Jacob & Governador Mangabeira & $\mathrm{S} 12^{\circ} 35^{\prime} 80^{\prime \prime}$ & W $039^{\circ} 06^{\prime} 81^{\prime \prime}$ \\
\hline JSF1 & Prop. Sr. Humberto & São Félix & S 12'41'93"' & W $039^{\circ} 02^{\prime} 30^{\prime \prime}$ \\
\hline JSF2 & Prop. Sr. Humberto & São Félix & S 12'41'93"' & W $039^{\circ} 02^{\prime} 30^{\prime \prime}$ \\
\hline JSF3 & Prop. Sr. Humberto & São Félix & S 12'41'93"' & W $039^{\circ} 02^{\prime} 30^{\prime \prime}$ \\
\hline JSF5 & Prop. Sr. Humberto & São Félix & S 12'41'93"' & W $039^{\circ} 02^{\prime} 30^{\prime \prime}$ \\
\hline JSF6 & Prop. Sr. Humberto & São Félix & S 12'41'93"' & W $039^{\circ} 02^{\prime} 30^{\prime \prime}$ \\
\hline JSF7 & Prop. Sr. Humberto & São Félix & S 12'41'93" & W $039^{\circ} 02^{\prime} 30^{\prime \prime}$ \\
\hline JSF8 & Prop. Sr. Humberto & São Félix & S 12'41'93"' & W $039^{\circ} 02^{\prime} 30^{\prime \prime}$ \\
\hline JSF9 & Prop. Sr. Humberto & São Félix & S 12\%41'93"' & W $039^{\circ} 02^{\prime} 30^{\prime \prime}$ \\
\hline JMG1 & Prop. D. Mariá & Maragogipe & S 12'42'07', & W $039^{\circ} 02^{\prime} 18^{\prime \prime}$ \\
\hline JMG2 & Prop. Sr. Vado & Maragogipe & S $12^{\circ} 47^{\prime} 18^{\prime \prime}$ & W $039^{\circ} 02^{\prime} 16^{\prime \prime}$ \\
\hline JMG3 & Prop. Sr. Vado & Maragogipe & S $12^{\circ} 47^{\prime} 15^{\prime \prime}$ & W $039^{\circ} 02^{\prime} 13^{\prime \prime}$ \\
\hline JMG4 & Prop. Sr. Olavo & Maragogipe & S 12³9'80" & W $039^{\circ} 06^{\prime} 27^{\prime \prime}$ \\
\hline JMG5 & Prop. Sr. Olavo & Maragogipe & S 12'49'07'” & $\mathrm{W} 039^{\circ} 02^{\prime} 41^{\prime \prime}$ \\
\hline JMG6 & Prop. Sr. Olavo & Maragogipe & S 12'49'08" & W $039^{\circ} 02^{\prime} 40^{\prime \prime}$ \\
\hline JMG7 & Prop. Sr. Olavo & Maragogipe & S 12'49'08" & W $039^{\circ} 02^{\prime} 40^{\prime \prime}$ \\
\hline JSFP1 & Prop. Sr. Dorinho & São Felipe & S 12॰44'67'” & W $039^{\circ} 05^{\prime} 33^{\prime \prime}$ \\
\hline JSFP2 & Prop. Sr. Dorinho & São Felipe & S $12^{\circ} 44^{\prime} 67^{\prime \prime}$ & W $039^{\circ} 05^{\prime} 33^{\prime \prime}$ \\
\hline JSFP3 & Prop. D. Lucinha & São Felipe & S $12^{\circ} 44.15^{\prime}$ & W $039^{\circ} 05.59^{\prime}$ \\
\hline JSFP4 & Prop. Sr. Inhozinho & São Felipe & S $12^{\circ} 45^{\prime} 02^{\prime \prime}$ & W $039^{\circ} 08^{\prime} 04^{\prime \prime}$ \\
\hline JSFP5 & Prop. Sr. Ademir & São Felipe & S $12^{\circ} 45^{\prime} 04^{\prime \prime}$ & W $039^{\circ} 04^{\prime} 84^{\prime \prime}$ \\
\hline JSA1 & Prop. Sr. João & Santo Antônio de Jesus & S $12^{\circ} 57^{\prime} 76^{\prime \prime}$ & $\mathrm{W} 039^{\circ} 15^{\prime} 45^{\prime \prime}$ \\
\hline
\end{tabular}


TABLE 2 - Sequence, amplification products, polymorphism percentage, polymorphic information content, and power of 18 ISSR primers used in 35 genotypes of jaboticabeira (Plinia sp.) collected in the Recôncavo da Bahia, BA.

\begin{tabular}{|c|c|c|c|c|c|c|}
\hline Primers & Sequence $\left(5^{\prime} \rightarrow 3^{\prime}\right)$ & TAF $^{(1)}$ & $\mathbf{N P F}^{(2)}$ & Polym $(\%)^{(3)}$ & $P_{I C}^{(4)}$ & $\mathbf{R P}^{(5)}$ \\
\hline $\operatorname{DiCA}^{\prime} \mathrm{G}^{* *}$ & GCACACACACACACACA & 30 & 30 & 100 & 0.23 & 12.51 \\
\hline $\operatorname{DiGA}^{\prime} \mathrm{C}^{* *}$ & GAGAGAGAGAGAGAGAC & 36 & 36 & 100 & 0.25 & 15.77 \\
\hline DiGA3'RC* & GAGAGAGAGAGAGAGARC & 14 & 14 & 100 & 0.26 & 5.60 \\
\hline DiGA3'YC** & GAGAGAGAGAGAGAGAYC & 26 & 26 & 100 & 0.29 & 8.85 \\
\hline TriCAC5' ${ }^{\prime} Y^{*}$ & CYCACCACCACCACCAC & 24 & 24 & 100 & 0.21 & 8.34 \\
\hline TriCAG* & CAGCAGCAGCAGCAG & 28 & 28 & 100 & 0.22 & 10.20 \\
\hline TriCAG5'CR* & CRCAGCAGCAGCAGCAG & 21 & 21 & 100 & 0.28 & 9.35 \\
\hline TriTGA 3'RC** & TGATGATGATGATGARC & 25 & 25 & 100 & 0.16 & 6.74 \\
\hline TriTGG 3'RC $* *$ & TGGTGGTGGTGGTGGRC & 28 & 28 & 100 & 0.24 & 10.36 \\
\hline TriCCT $3{ }^{\prime} \mathrm{RC}^{* *}$ & CCTCCTCСТCCTCCTRC & 19 & 19 & 100 & 0.21 & 5.35 \\
\hline TriCGA 3’RC* & CGACGACGACGACGARC & 24 & 24 & 100 & 0.13 & 4.34 \\
\hline TriCGC 3'RC** & CGCCGCCGCCGCCGCRC & 29 & 29 & 100 & 0.14 & 5.43 \\
\hline TriCGG 3'RC ${ }^{* *}$ & CGGCGGCGGCGGCGGRC & 30 & 30 & 100 & 0.19 & 8.86 \\
\hline TriGAG 3’RC* & GAGGAGGAGGAGGAGRC & 25 & 25 & 100 & 0.33 & 8.98 \\
\hline TriGTA 3’RC* & GTAGTAGTAGTAGTARC & 22 & 22 & 100 & 0.20 & 6,38 \\
\hline TriGTC $3^{\prime} \mathrm{RC}^{* *}$ & GTCGTCGTCGTCGTCRC & 33 & 33 & 100 & 0.23 & 12.86 \\
\hline TriGCC $3^{\prime} \mathrm{RC}^{* *}$ & GCCGCCGCCGCCGCCRC & 33 & 33 & 100 & 0.22 & 10.69 \\
\hline TriGGA 3'RC* & GGAGGAGGAGGAGGARC & 16 & 15 & 93.75 & 0.21 & 5.37 \\
\hline Total & & 463 & 462 & - & - & - \\
\hline Average & & 25.72 & 25.67 & 99.65 & 0.22 & 8.67 \\
\hline
\end{tabular}

(1)TAF: total of amplified fragments. (2)NFP: number of polymorphic fragments. (3) Polym(\%): Percentage of polymorphism. (4)PIC: polymorphic information content. (5)RP: resolution power of the primer.

*VIDAL et al. (2015)

**Eder Jorge de Oliveira - Embrapa Mandioca e Fruticultura (Personal communication).

M $1 \quad 2 \quad 3 \quad 4 \quad 5 \quad 6 \quad 7 \quad 8 \quad 9 \quad 10111213141516171819202122 \quad 23242526272829303132333435$

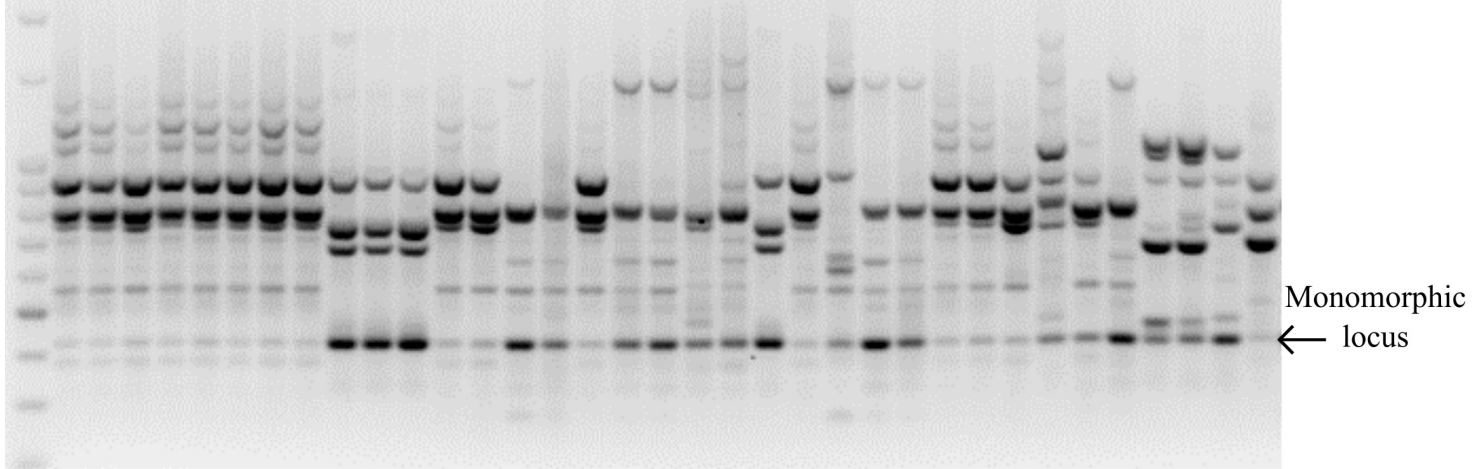

FIGURE 1- Electrophoretic profile obtained by the DNA amplification in 35 genotypes of jaboticabeira using the primer DiGA3'C, and the ISSR technique. M: molecular weight marker $100 \mathrm{pb}$, DNA Ladder da Ludwig Biotec. 


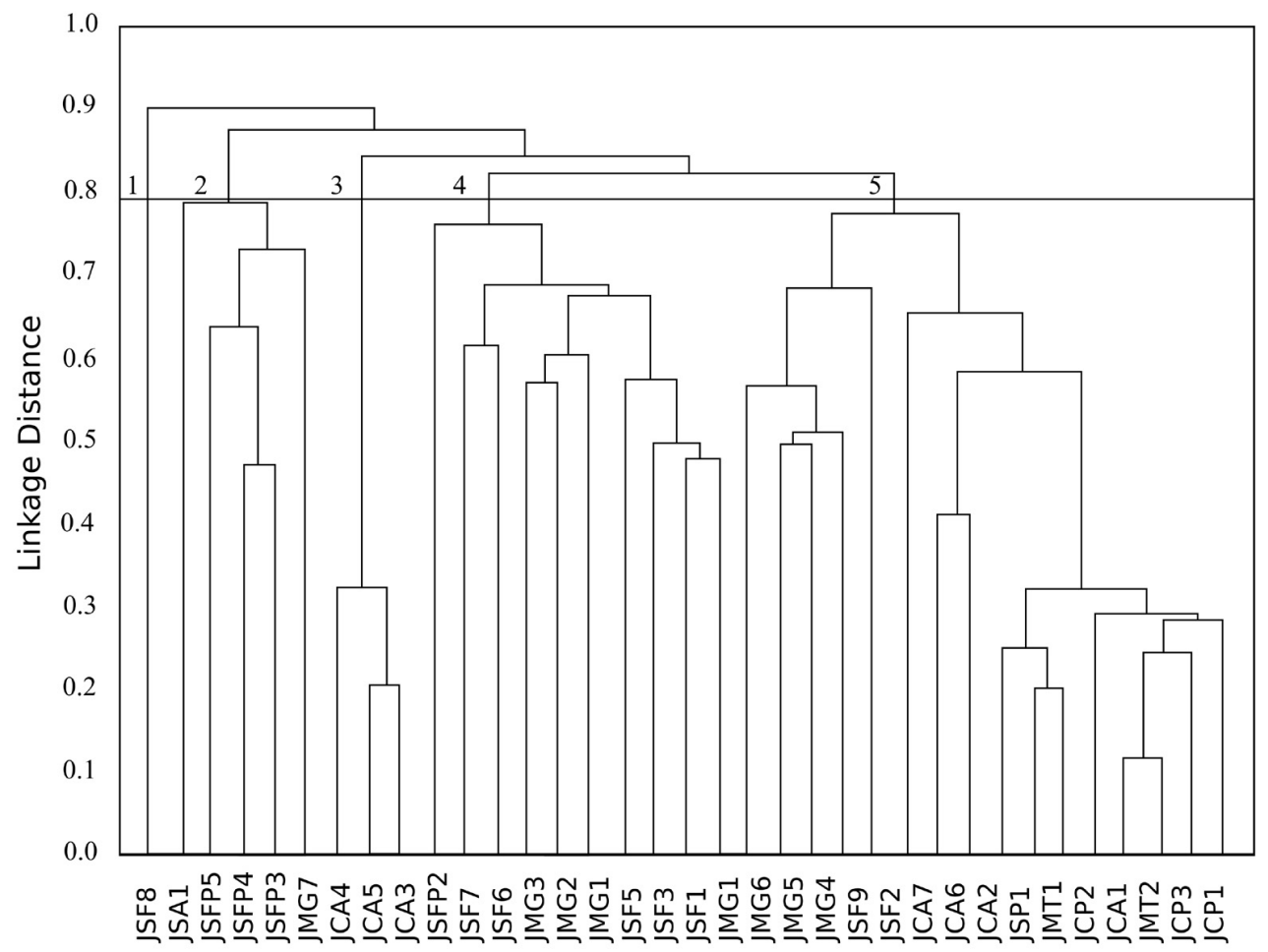

FIGURE 2- Dissimilarity dendrogram among 35 genotypes of jaboticabeira (Plinia sp.) located in the Recôncavo da Bahia, base on the molecular characterization and obtained by the UPGMA method based on the average Euclidean distance . $\mathrm{CCC}=0.97$.

\section{CONCLUSION}

Based on the use of ISSR primers, it is possible to verify the existing variability among the genotypes of jaboticabeira evaluated.

\section{ACKNOWLEDGEMENTS}

To the Bahia State Research Support Foundation (FAPESB), for the scholarship granted and financial assistance.

\section{REFERENCES}

AGUIAR, R.V.; CANSIAN, R.L.; KUBIAK, G.B.; SLAVIERO. L.B.; TOMAZONI, T.A.; BUDKE, J.C.; MOSSI, A. J. Variabilidade genética de Eugenia uniflora L. em remanescentes florestais em diferentes estádios sucessionais. Revista Ceres, Viçosa, MG, v.60, n.2, 2013.

BOTSTEIN, D.; WHITE, R. L.; SKOLNICK, M.; DAVIS, R.W. Construction of a genetic linkage map in man using restriction fragment length polymorphisms. American Jornal Human Genetics, Houston, v.32, p.314-331, 1980.

BRANDÃO, M. M., VIEIRA, F. de A.; CARVALHO, D. de. Estrutura genética em microescala espacial de Myrcia splendens (Myrtaceae). Revista Árvore, Viçosa, MG, v.35, p.957-964, 2011 
CHARRAD, M.; GHAZZALI, N.; BOITEAU, V.; NIKNAFS, A. NbClust: An R Package for Determining the Relevant Number of Clusters in a Data Set. Journal of Statistical Software, Los Angeles, v.61, n.6, p. 1-36, 2014.

COSTA, I. R. da; FORNI-MARTINS, E. R. Chromosome studies in species of Eugenia, Myrciaria and Plinia (Myrtaceae) from south-eastern Brazil. Australian Journal of Botany, Melbourne, v.54, p.409-415, 2006.

CRUZ, C. D.; CARNEIRO, P. C. S. Diversidade genética. In: CRUZ, C. D.; CARNEIRO, P. C. S. (Ed.). Modelos biométricos aplicados ao melhoramento genético. Viçosa: UFV, 2003. v.2, p.357-434.

CRUZ, C. D. Programa genes (versão Windows): aplicativo computacional em genética e estatística. Viçosa: UFV, 2008.

DANNER, M. A.; CITADIN, I.; SASSO, S. A. Z.; SACHET, M. R.; MAZARO, S. M. Germplasm characterization of three jabuticaba tree species. Revista Brasileira de Fruticultura, Jaboticabal, v.33, n.3, p.839-847, 2011 a.

DANNER, M. A.; CITADIN, I.; SASSO, S. A. Z.; SACHET, M. R.; MALAGI, G. Modo de reprodução e viabilidade de pólen de três espécies de jabuticabeira. Revista Brasileira de Fruticultura, Jaboticabal, v. 33, n. 2, p. 345-352, 2011 b.

DIAS, F. T. C.; BERTINI, C. H. C. de M.; SILVA, A. P. M. da; CAVALCANTI, J. J. V. Variabilidade genética de feijão-caupi de porte ereto e ciclo precoce analisada por marcadores RAPD e ISSR. Revista Ciência Agronômica, Fortaleza, v.46, n.3, 2015.

DUDA, R. O.; HART, P. E. Pattern classification and scene analysis. New York: John Wiley and Sons, 1973.

FERREIRA, M. E.; GRATTAPAGLiA, D. Introdução ao uso de marcadores moleculares em análise genética. 3.ed. Brasília: Embrapa Cenargen, 2008. 220p. (Documentos, 20).
GOULÃO, L.; OLIVEIRA, C. M. Molecular characterization of cultivars of apple (Malus domestica Borkh.) using microsatellite (SSR and ISSR) markers. Euphytica, Wageningen, v.122, p.81-89, 2001.GUEDES, M. N. S.; RUFINI, J. C. M.; AZEVEDO, A. M.; PINTO, N. A. V. D. Fruit quality of jabuticaba progenies cultivated in a tropical climate of altitude. Fruits, Paris, v.69, p. 449-458, 2014.

JACCARD, P. Étude comparative de la distribution florale dans une portion des Alpes et des Jura. Bulletin de la Société Vaudoise des Sciences Naturelles, Lancaster, v. 37, p. 547-579. 1901. (1)

LODHI, M. A.; YE, N. G.; WEEDEN, N. F.; REICH, B. I. A simple and efficient method for DNA extraction from grapevine cultivars and Vitis species. Plant Molecular Biology Reporter, Ottawa, v.12, p.6-13, 1994

MANI, A.; MISHRA, R.; THOMAS, G. Elucidation of diversity among psidium species using morphological and SPAR methods. Journal of Phytology, Allahabad, v.3, n.8, p.53-61, 2011.

MELO, A. T. de O.; COELHO, A. S. G.; PEREIRA, M. F.; BLANCO, A. J. V.; FRANCESCHINELLI, E. V. Genética da conservação de Cabralea canjerana (vell.) Mart. (meliaceae) em fragmentos florestais de mata atlântica na APA Fernão Dias. Revista Árvore, Viçosa, MG, v.39, n.2, p.365-374, 2015.

OLADOSU, Y.; RAFII, M.Y.; ABDULLAH, N.; MALEK, M. A.; RAHIM, H. A.; HUSSIN, G.; ISMAIL, M. R.; LATIF, M. A.; KAREEM, I. Genetic variability and diversity of mutant rice revealed by quantitative traits and molecular markers. Agrociencia, México, v.49, n.3, 2015.

OLIVEIRA, N. N. S. de; VIANA, A. P.; QUINTAL, S. S. R.; PAIVA, C. L.; MARINHO, C. S. Análise de distância genética entre acessos do gênero Psidium via marcadores ISSR. Revista Brasileira de Fruticultura, Jaboticabal, v.36, n.4, p.917-923, 2014.

PEREIRA, M.; OLIVEIRA, A. L. de; PEREIRA, R. E. de A.; SENA, J. A. D.; COSTA, J. R. V. da; ALMEIDA, M. de; GONÇALVES, A. N. Caracterização morfológica e molecular de espécies de Myrciaria spp., Revista Brasileira de Fruticultura, Jaboticabal, v.27, n3, p.507-510, 2005. 
PREVOST, A.; WILKINSON, M. J. A new system of comparing PCR iniciadores applied to ISSR fingerprinting of potato cultivars. Theory Applicate Genetics, Heidelberg, v.98, p.107-112, 1999.

R DEVELOPMENT CORE TEAM. R: a language and environment for statistical computing, reference index version 3.0.3. Vienna: R Foundation For Statistical Computing, 2013.

REDDY, M. P; SARLA, N.; SIDDIQ, E. A. Intersimple sequence repeat (ISSR) polymorphism and its application in plant breeding. Euphytica, Wageningen, v.128. p.9-12, 2002.

ROHLF, F. J.; FISHER D. L. Test for hierarchical structure in random data sets. Systematic Zoology, Washington, v.17, p.407-412, 1968.

SASSO, S. A. Z.; CITADIN, I.; DANNER, M. A. Propagação de jabuticabeira por enxertia ou alporquia. Revista Brasileira de Fruticultura, Jaboticabal, v. 32, n. 2, p.571-576, 2010.

SILVEIRA, F.T.; ORTOLANI, F. A.; MATAQUEIRO, M. F.; MORO, J. R. Caracterização citogenética em duas espécies do gênero Myrciaria. Revista de Biologia e Ciências da Terra, Campina Grande, v.6, n.2, p.327-333, 2006.

SNEATH, P. H.; SOKAL, R. R. Numerical taxonomy: the principles and practice of numerical classification. San Francisco: W.H Freeman, 1973. $573 \mathrm{p}$.

SOBRAL, M. Alterações nomenclaturais em Plinia (Myrtaceae). Boletim do Museu Botânico de Curitiba, Curitiba, n. 63, p.1-4, 1985.
SOUZA, D. C. L. Técnicas moleculares para caracterização e conservação de plantas medicinais e aromáticas: uma revisão. Revista Brasileira de Plantas Medicinais, Campinas, v.17, n.3, p.495503, 2015.

STATSOFT. Statistica for windows (data analysis software system). version 7.1. Tulsa, 2005.

TATIKONDA, L.; WANI, S. P.; KANNAN, S.; BEERELLI, N.; SREEDEVI, T. K.; HOISINGTON, D. A.; DEVI, P.; VARSHNEY, R. K. AFLP-based molecular characterization of an elite germplasm collection of Jatropha curcas L. biofuel plant. Plant Science, Limerick, v.176, p.505-513, 2009.

VIDAL , A. M., VIEIRA, L. J; FERREIRA, C. F.; SOUZA, F. V. D.; SOUZA, A. S.; LEDO, C. A. S. Genetic fidelity and variability of micropropagated cassava plants (Manihot esculenta Crantz) evaluated using ISSR markers. Genetics and Molecular Research, Ribeirão Preto, v.14, n.3, p.7759-7770, 2015.

VILELA, R. C. F.; ASSIS, J. G. A. de A.; NOBREGA FILHO, L.; FELIPE, B. Sistema reprodutivo e diversidade genética de quatro espécies de Myrciaria (Myrtaceae, jabuticabeiras). Acta Botanica, Brasília, v.26, n.4, p.727-734, 2012.

WAGNER JUNIOR, A.; SILVA, J. O. da C. e; PIMENTEL, L. D.; SANTOS, C. E. M. dos; BRUCKNER, C. H. Germinação e desenvolvimento inicial de duas espécies de jabuticabeira em função do tamanho de sementes. Acta Scientiarum Agronomy, Maringá, v.33, n.1, p.105-109, 2011.

WEIR, B. S. Genetic data analysis: methods for discrete population genetic data. Sunderland: Sinauer Associates, 1990. 